九州大学学術情報リポジトリ

Kyushu University Institutional Repository

\title{
A NEW SPECIES OF THE ANT GENUS EPZTRZTUS EMERY FROM JAPAN (HYMENOPTERA, FORMICIDAE)
}

Ogata, Kazuo

https://doi.org/10.5109/2544

出版情報: ESAKIA. Special Issue 1, pp.197-199, 1990-04-20. Entomological Laboratory, Faculty of Agriculture, Kyushu University バージョン :

権利関係 : 


\title{
A NEW SPECIES OF THE ANT GENUS EPZTRZTUS EMERY FROM JAPAN (HYMENOPTERA, FORMICIDAE)*
}

\author{
KazUo Og A T A \\ Entomological Laboratory, Faculty of Agriculture, \\ Kyushu University, Fukuoka, 812 Japan
}

\begin{abstract}
A new species, Epitritus hirashimai, is described from southwestern part of Japan based on workers. This new species is easily distinguished from another Japanese species $E$. hexamerus by the shape of mandibles and the mesonotal profile. This is the eighth species of the genus.
\end{abstract}

The ant Epitritus is a small dacetine genus, distributed from the warmer temperate to tropical areas of the Old World. Up to present 7 species have been described : 4 in the Afrotropical region, 1 in Mediterranean area and 2 in Asia (Bolton, 1983). The genus is characteristic in having the bilobate labrum and the linear mandibles which lack apical fork of spinifom teeth.

Although the genus has been represented by only one described species, E. hexamerus Brown, in Japan, the occurrence of the second species has been recognized by several Japanese myrmecologists (cf. "A list of the Ants of Japan" ed. by the Myrmecologists Society (Japan), 1988). The author reexamined the undetermined material collected from various localities of southwestern Japan, and found that the species is new to science.

Before going further, I wish to express my sincere thanks to Prof. Emeritus Y. Hirashima and Prof. K. Morimoto, Entomological Laboratory, Kyushu University, for their constant guidance and encouragement. I am much indebted to the following persons who kindly offered the valuable material : Dr. K. Onoyama, Obihiro University of Agriculture and Verterinary Medicine, Obihiro, Mr. M. Terayama, Tokyo, Mr. K. Murata, Utsunomiya, Dr. A. Miyata, Oita, and Mr. H. Takamine, Naha.

Epitritus hirushimai n. sp. (Figs. 1-3)

Worker : TL 1.1-1.4 mm, HL 0.40-0.46 mm, HW 0.36-0.40 mm, CI 82-95, ML 0.12-0.14 mm, MI 2733, SL 0.20-0.24 mm, SI 55-63, PW 0.20-0.24 mm, AL 0.42-0.48 mm (11 measured ; for the definitions of measurements, indices and their abbreviations see Bolton, 1983).

Head slightly longer than broad, with flattened dorsum ; posterior margin roundly and shallowly emarginate with low occipital carina. Mandibles without preapical teeth ; masticatory margin

* Contribution from the Entomological Laboratory, Faculty of Agriculture, Kyushu University, Fukuoka (Ser. 4, No. 8). 


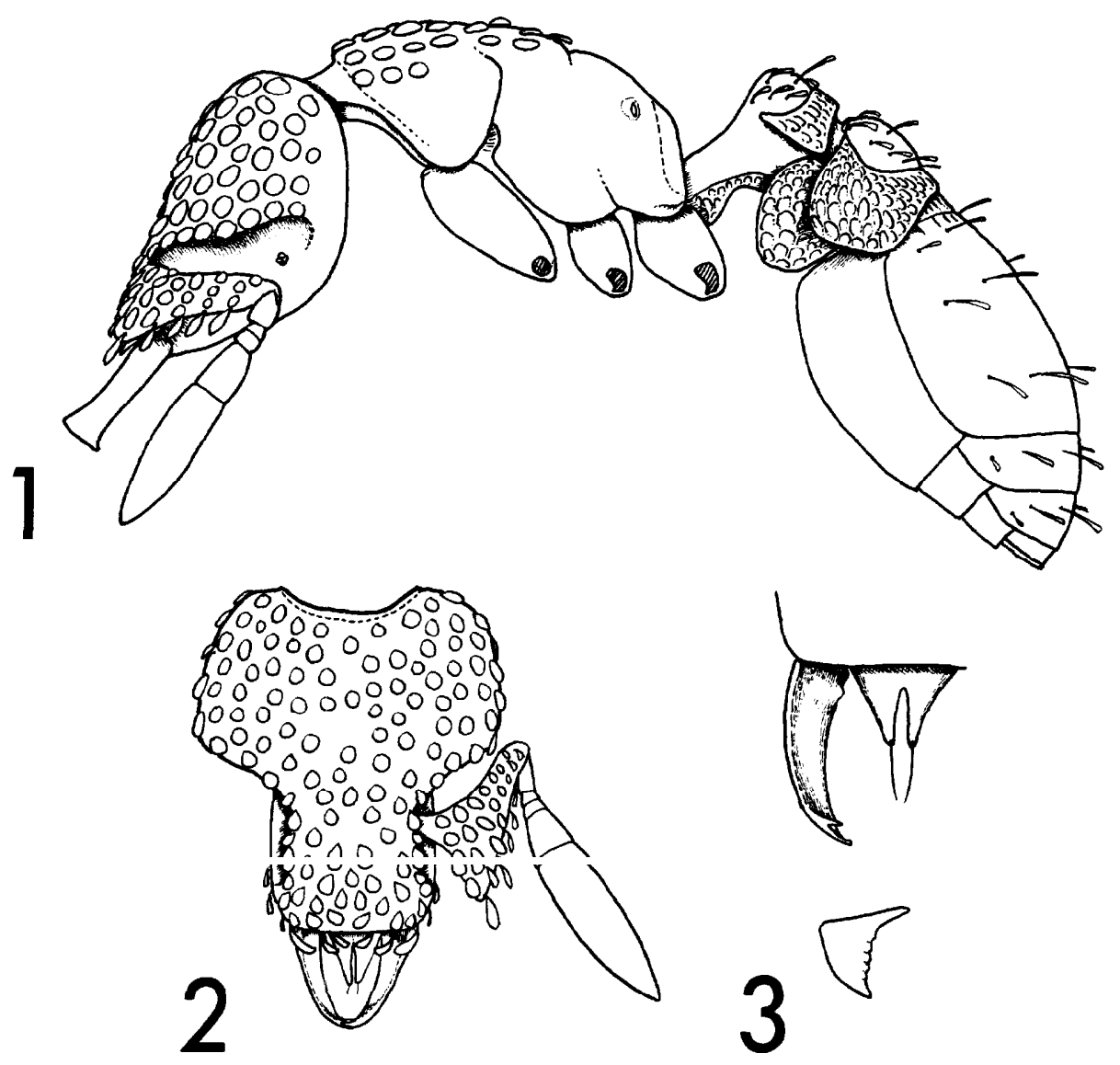

Figs. 1-3. Epitritus hirashimai n. sp. 1, worker, lateral view ; 2, same, head, frontal view; 3, right mandible, (above - dorsal view, below - anterior view).

broadened almost vertically, with small but acute dorsal spiniform tooth and smaller ventral one which do not form fork-like structure as in Strumigenys; intercalary with 4-5 indistinct minute teeth. Apical portion of labrum with two distinct lobes which are visible in frontal view. Clypeus flattened with almost straight anterior margin and rounded lateral comers. Antennae 6-segmented ;scape depressed, with distinct subbasal lobe forming acute angle ; third and fourth antennal segments small, their combined length shorter than $1 / 2$ of second antennal segment ; apical segment long, almost $3 \mathrm{X}$ as long as preapical one. Eyes small, consisting of 4 to 5 facets.

Pronotum marginate anteriorly and depressed ; broadest at anterior $1 / 3$ of whole length of trunk in dorsal view. Promesonotal suture indistinct. Mesonotum less raised, not overriding on propodeum. Metanotal groove distinct dorsally. Propodeum with gently sloped dorsal surface and distinct posterior lamelliform appendages, but without dentiform projections posterodorsally. Petiole with narrow anterior peduncle and with low and rounded node. Postpetiolar node depressed. Spongiform appendage well developed on petiole and postpetiole.

Mandible shallowly and coarsely punctate. Dorsum of head including clypeus, antennal scapes, dorsum of promesonotal area of trunk, legs petiole and postpetiole reticulate ; the remainder of body 
smooth and shining. Orbicular hairs present on dorsal surface of head, scapes and promesonotal area ; spatulate hairs present on anterior margin of clypeus (three pairs), outer margin of scape, legs, dorsum of petiole and postpetiole ; clavate hairs standing on petiole postpetiole and gaster.

HolotyPe : Worker (Type No. 2792, Kyushu Univ.), Toshima Is., Izu IsIs., 27. iii. 1986, K. Murata et M. Terayama leg.

PARATYPES: 54 workers, same data as holotype; 1 workers, Kuroko Is., Hirado, Nagasaki Pref., 6. ix. 1982 (K. Ogata \& S. Eto) ; 4 workers, Hazama, Oita Pref., 5. xi. 1985 (A. Miyata) ; 2 workers, Izuhara-Ariakeyama (Izuhara-Jinjya Shrine), Tsushima Is., Nagasaki Pref., 25. ix. 1959 (T. Hidaka, K. Morimoto \& T. Kawarabata) ; 3 workers, Mt. Yuwan, Amami-Oshima Is., 16. viii. 1986 (H. Takamine).

Remarks : The species is rare. Most of the material were found in soil. The two Japanese species are separated by the following characters:

\section{hexamerus}

Size larger (HW $0.5 \mathrm{~mm}$ or more)

Mandibles with two pairs of preapical teeth

Mesonotum overriding propodeum

Propodeum with paired posterior projections

\section{hirashimai}

Size smaller (HW $0.4 \mathrm{~mm}$ or less)

Mandibles without preapical teeth

Mesonotum not overriding propodeum

Propodeum without paired posterior projections

The absence of preapical teeth on mandibles and less raised mesonotal profile in hirashimai are also available for separating from another Asian species E.murphyi Taylor of West Malaysia and Sarawak. These character states are found in E.minimusBolton from West Africa. But the latter has 4-segmented antennae.

In the check list of Japanese ants published by the Myrmecologists Society, Japan (1988), the species was distinguished as Epitritus sp. 2 with the Japanese name, "himesedaka-urokoari". This new species is named after Professor Yoshihiro Hirashima in honor of his retirement from the Entomological Laboratory, Kyushu University.

\section{References}

Bolton, B., 1983. The Afrotropical dacetine ants (Formicidae). Bull.Brit.Mus. nat. Hist. (Ent.), 46 : 267-416.

Brown, W. L., Jr., 1958. A new Japanese species of the dacetine ant genus Epitritus. Mushi, 31: 6972.

The Myrmecologists Society (Japan“) (ed.), 1988. A list of the ants of Japan with common Japanese names. 50 pp. Tokyo. 